\title{
PROVERBS AND MEDICINE: THE PROBLEM OF APPLIED FOLKLORE
}

\author{
Larisa Fialkova
}

\begin{abstract}
The difference between medical proverbs and proverbs in medicine has been largely ignored. The former are proverbs used for medical purposes even though they may have no medical content. The perception of a proverb as medical in content is flexible, varying from collection to collection. In thematic proverb collections the items are usually taken out of the context but their very inclusion is in itself a context-specifying factor. A new definition of applied folklore is proposed, stressing the role of non-folklorists. The wish to use proverbs for concrete purposes inheres in the material itself as much as the wish to reveal its universal formulas.
\end{abstract}

Key words: applied folklore, medicine and humanities, proverbs in medicine, thematic collections

\section{INTRODUCTION: NEVER SAY NEVER}

Several years ago Prof. Arvo Krikmann published his paper on animal metaphors in proverbs. He informed his readers that he was publishing it after becoming disillusioned with the topic, which initially had been designed for his doctoral dissertation (Krikmann 2001: 11). This confession encourages me to open this article, which is intended for publication in this journal's issue honouring Prof. Krikmann's jubilee, with an admission of my own. My interest in medical proverbs began in my early student years, when my father, a physician, suggested this topic to me as a joint venture. For two years we searched for medical proverbs in various collections, discussing the criteria for the notion "medical" and for the classification of our material. Concurrently with our joint collecting activities I completed my seminar paper and even published a short paper, which I do not include in my list of publications. At that point I began to harbour misgivings as to the scientific value of the topic, and I took the opportunity to discuss them with two venerable literary scholars, Miron Petrovskii and Vadim Skuratovskii. Their verdict was unanimous: although the collection was interesting and the seminar work showed a student's ability in research, the topic itself had no philological value. Both the collection and 
the seminar paper might be published as a popular piece for general readership. Although presented to me very politely and amiably, this conclusion caused me a profound psychological trauma. For six months I could write nothing at all, and then I switched abruptly from folklore to literary studies. My emigration in 1991 caused me to return to the path of folklore studies, but one angle of it, namely medical proverbs, remained previously sealed for me and thus my father must be again mentioned. He carried our collection in his immigrant luggage; he even brought along my old seminar paper. For thirty years he tried to persuade me to publish our collection, occasionally encountering "explosions" from myself. He refused to publish it under his own name, although I ardently suggested that he do so and while I said "never", he still waited patiently. Then, suddenly, the situation changed when two years ago, in one of our numerous fervent debates on medical proverbs it struck me that my father was growing old. This understanding changed the whole perspective of the issue so I was not about to deprive him of one of the few pleasures remaining to him. The fear that he might not see this work published, and I would blame myself for it, was bitterer than the memory of my failure so long ago. And so I agreed to publish the book of medical proverbs, with the proviso that he typed it out himself on the computer and as my father was still not really computer literate the task was enormous. But he accomplished it, and even added many Jewish proverbs himself and so the upshot is that our book has been published. And my paper on medical proverbs can be viewed as one of the confirmations of the wise folk sayings - "Never say never".

\section{MEDICAL PROVERBS AND PROVERBS IN MEDICINE}

Any distinction between medical proverbs and proverbs in medicine may seem odd or even non-existent. It is disregarded in both medical and folklore studies. Scholars simply deal with either of these types without specifying them. But the difference should be defined as not all the proverbs used by medical practitioners are medical in content; and medical content does not automatically imply the use of these items in medicine.

Medical proverbs and proverbial sayings uttered by people constitute pithy observations, opinions and advices across a whole array of human existence, covering life, death, illnesses, and relations of doctors and patients. Russell A. Elmquist introduced the notions of indirect and direct references to physiological matters in proverbs and proverbial sayings, limiting his research to the latter group (Elmquist 1934: 75). In principle, I accept this dichotomy, although Elmquist's examples of indirect references to physiological matters are, I be- 
lieve, completely out of place. I see no physiological significance in such proverbs as "A new broom sweeps clean" or "Coming events cast their shadows before" (Elmquist 1934: 75). To my mind, the narrow cluster of medical proverbs includes those about illness, pain, doctors, patients, folk healers, healthy and unhealthy habits, medication, and diagnostic and prognostic proverbs, while a broad cluster also encompasses proverbs and sayings about life and death, general ideas about age and so on. To the best of my knowledge, the collections of medical proverbs are not limited to the narrow group, which is as it should be. The borders between health and illness, age and illness, and even life and death, are permeable and cannot be sealed. It has been noted that the proverbs' reflection of the "actual healing art is poor" (Garrison, 1928: 984; Anonymous 1914: 875) and that they "are not particularly enlightening from the scientific point of view" (Mieder 1993: 153). For all that medical proverbs were and remain in demand, as they are perceived as a true reflection of people's worldview and a source of good counsel (Zakharov \& Zhungietu 1975: 5-6). Latin medical proverbs are known from late Antiquity while collections of medical proverbs exist since the Middle Ages (Mieder 1993: 152-153). Medical proverbs might equally be included in general collections as separate chapters (Dal' 1957). Past and present collections of such proverbs have been compiled by medical doctors and/or by specialists in humanities (folklorists, linguists, etc.). Sometimes both roles are combined in one person (e.g. Vladimir Dal', who was both a physician and a great linguist) or in a single team of a physician or a biologist and a folklorist (Fialkov \& Fialkova 2009; Zakharov \& Zhungietu 1975). In other cases, the work can be accomplished by physicians and psychologists themselves (Dudnikov 1969; Kadymov 1971; Zhitnikova \& Polivanova 2001) or by a folklorist with no medical education (Sysoev 2007). The intended readership of such publications varies between the general public and medical personnel. With the former, the aim of publication is usually to disseminate medical information in a popular form easy to remember (Kadymov 1971; Sysoev 2007; Zakharov \& Zhungietu 1975); with the latter, it is to provide doctors and psychologists (both at the clinic and in their teaching activities) with lively material to facilitate their communication with patients or with an audience (Dunaevskii 1965; Zhitnikova \& Polivanova 2001). Whichever audience is targeted does not influence the type of the material, although it becomes more important in the case of analyses (Zhitnikov \& Polivanova 2001). In any event, the books in question are not meant for professional folklorists.

Proverbs are used in medicine in various ways. Some are indeed medical proverbs, functioning in the way set out above. Others, although deprived of medical content, are nevertheless an integral part of medical discourse. An 
example is, "When you hear hoofbeats, think horses, not zebras". This text, taken out of the context, has no indication of medical content at all. Yet as shown by Alan Dundes and colleagues, it is used in a number of variations by doctors in their papers published in professional medical journals. Hoofbeats in this context are deciphered as symptoms of a disorder presaging common diseases (horses) or rare and/or exotic ones (zebras). Here we have a clear example of an in-group proverb which, taken out of professional discourse, loses its medical character entirely. So to my mind the notion "diagnostic", applied to this proverb by Dundes and colleagues is inaccurate (Dundes et al. 2008). This term should be reserved for proverbs with obvious medical diagnostic content such as "If he has blue veins on the nose, he'll never wear his wedding clothes" (Elmquist 1934: 79-80), Nebo zhelteet $k$ dozhdiu, chelovek $k$ bolezni ('The sky turns yellow before rain, a person - before illness'), Gde kashel' - tam i khvor' ('The cough comes with the illness') (Fialkov \& Fialkova 2009: 74, 86). But the proverb about the horses and zebras suits another paradigm, namely, informal medical discourse (Stoianova 2007).

Proverbs are often used as a clinical test for schizophrenia, as well as aphasia and Alzheimer's disease. The rationale rests on patients' impaired abstract mental abilities, that is, their capacity or failure to distinguish a proverb's metaphoric form from its literal meaning. The test uses both the multiplechoice and the free-answer techniques, the former consisting of 40 items, each with four possible answers; the latter comprises 12 items, scaled in order of difficulty. The free-answer test is more reliable, especially with the high intelligence group (Gorham 1956). Other authors have attempted to improve the test's reliability by including the factor of familiarity/non-familiarity with the proverbs (Ulatowska et al. 1995) and/or the free oral form of the proverbs' interpretation, which was videotaped and transcribed for rating (Sponheim et al.2003: 118-119). Wolfgang Mieder pointed out that the items in the proverbs test are extracted from their context, which is of crucial importance for their understanding (Mieder 2004: 142). I would like to add that to my knowledge the papers on the application of the proverbs test in psychiatry published in medical journals carry no references whatsoever to research of proverbs in folklore. This indicates that the tests are designed by people whose understanding of the proverbs is that of the lay public, not of professionals.

A context-related approach to proverbs can be found in the writings of psychiatric and/or geriatric social workers, whose daily contact with patients requires mobilization of informal resources. Proverbs are important for gaining information about the patients' mental state when open discussion is suppressed by cultural norms, as in the case of Israeli Bedouins, and/or for facilitating of contact among the patients themselves or between them and the staff. Prov- 
erbs in this case are part of the subjects' repertoire and belief system. Some of them have evident medical content: "An apple a day keeps a doctor away", "An ounce of prevention is worth a pound of cure" (Jackson 1995: 8), "After much patience and frustration the situation will lead to the grave" (Al-Krenawi: 2000: 99). The last item can be likened to a Moldavian proverb Esli tebia odolevaet gore $i$ pechal, beris' $z$ a lopatu ('If you are overburdened with sorrow and grief, take a shovel') (Fialkov \& Fialkova 2009: 127). Nevertheless, proverbs in medical use can be without distinct medical content. As an example I can quote a proverb: "The second wife is very sour even if it is a handle of the pot" (Al-Krenawi 2000: 98); used by a wife in a polygamous family, this conveys a cause of psychological distress. This context-oriented approach to proverbs in medical settings may be based on some knowledge of folklore studies (Al-Krenawi 2000) or be completely devoid of it (Jackson 1995).

\section{MEDICAL PROVERBS: MATERIAL, TOPICS, CLASSIFICATION AND USE}

The multiplicity of universal proverbs and the limitations of the topic itself have contributed to the existence of many identical items in the diverse collections. However, they vary in the plethora of their understandings of "medical" and in their principles of classification. Medical proverbs are quite often combined with aphorisms spoken by figures from various times and peoples (Garrison 1928; Dudnikov 1969; Kadymov 1971; Zakharov \& Zhungietu 1975; Sysoev 2007), while other collections contain only folk material (Dunaevskii 1969; Elmquist 1934; Fialkov \& Fialkova 2009; Vysotskii 1903). Present almost always are rubrics which correspond to the narrow understanding of "medical", namely "Health", "Illness", "Treatment", "Bad Habits" (or alternatively "Alcohol", "Smoking"), and "Sleep". A broad understanding can embrace such rubrics as "Love, family", "Sport", "Appearance of a person", and "Man and nature" (Zakharov \& Zhungietu 1975), "The role of labor", "Family, children, upbringing" (Kadymov 1971); "The wise way of life" (Sysoev 2007) and more. The choice of items under each heading may also be more rigid or less. Non-medical proverbs found include Na vkus i tsvet tovarishcha net ('There is no friend in color and taste'), Vkus pel'menei $v$ miase ('The taste of meat dumplings is in meat') (Zakharov \& Zhungietu 1975: 120), Delaia zlo, na dobro ne nadeisia ('If you do bad things, don't hope to get something good') (Sysoev 2007: 12), "The fox never found a better messenger than himself" (Garrison 1928: 983), etc.

The items are generally set under the rubrics in alphabetical order, as is usual in any general collection of proverbs. In a book of proverbs from various 
peoples, they are usually assembled according to the thematic heading. However, in Sysoev's book only Russian proverbs come under specific rubrics; proverbs of other peoples are placed after the Russian ones under the name of the nation, two to six for each, irrespectively of their sub-thematic content (Sysoev 2007: 79-94). In our own collection (Fialkov \& Fialkova 2009) we decided to evade alphabetical order, so we put the proverbs together in blocks based on the same, a synonymous or a contrasting image, for example:

Vrach sam sebia ne lechit ('A doctor can't cure himself' - Tamil),

Vrach khorosho lechit chuzhie bolezni ('A doctor cures well the illnesses of others' - Jewish),

Vrach, uvrachui snachala svoi nedug ('Doctor, cure yourself first' - Russian),

Lekar' ne mozhet lechit' sebia sam ('Doctor can't cure himself' - Zulu),

Sam ne mozhet izbavit'sia ot bolezni, a drugikh lechit ('He can't cure himself and yet he treats others' - Moldavian),

Koli ty khirurg, vprav' snachala sobstvennye kishki ('If you are a surgeon, set your own guts first' - Persian),

Liudei ot nasmorka lechit, a sam nasmorkom izoshiel ('He treats people for a sniffle, while he is sniffling himself' - Russian),

Mozhet li lekar' vylechit' drugikh, esli bolen sam? ('Can a doctor cure the others if he himself is ill?' - Hindi),

Kak vrach ni khorosh - samomy sebe ne pomozhet ('Even the best doctor can't cure himself' - Kalmyk),

Vrach o svoiem zdorovie ne zabotitsia ('A doctor doesn't look after his own health' - Japanese). (Fialkov \& Fialkova 2009: 102-103)

Posmotri na tsvet litsa i sprosi o zdorovie ('Look at the color of the face and then ask about the health' - Persian),

Snachala posmotri na tsvet litsa, a potom sprashivai o zdorovie ('At first look at the color of the face and only then ask about the health' - Tajik),

Nebo zhelteet $k$ dozhdiu - chelovek $k$ bolezni ('The sky turns yellow before rain, a person - before illness' - Chinese),

Den' merknet ot nochi, a chelovek ot nemochi ('The day grows dark because of night, while a man because of illness' - Ukrainian), 
Den' merknet nochiu, a chelovek pechaliu ('The day darkens at night, a man because of grief' - Russian). (Fialkov \& Fialkova 2009: 86-87)

In my 1977 seminar paper, written when the book was almost compiled, I explained this classification as the path to a scientific definition of medical proverbs, which at that time I perceived as a separate type with distinctive features. Today, having completely abandoned that idea, I still consider this classification appropriate for applied folklore. Clusters of proverbs based on a certain idea, with corresponding images and belonging to various cultures, furnish some kind of inner discourse and simultaneously accentuate the items' universality and cultural specifics alike. In fact, this classification is the opposite of the scientific structural approach based on the form, not the image (Dundes 1994: 45-46). It adds nothing to our understanding of proverbs as a genre, but can be utilized in concrete activities with the audience.

In my search for scientific papers on medical proverbs I found several in English and only one in Russian. This was by Nikolai Fedorovich Vysotskii, a professor of surgery and pathology from Kazan University, written early in the 20th century (Vysotskii 1903). For T. L. Zhitnikova and E. A. Polivanova (2001) proverbs served as an additional source, while their study consisted mainly of analyses of jokes. For that reason, although many items in contemporary Russian-language collections are indeed Russian proverbs, I can compare their content mostly with the observations made in the West.

The unnamed author of "Proverbial Medicine" pointed out a number of proverbs containing a link between a specific month (May or July) with death (Anonymous 1914). Vysotskii published two items linking the systematic deterioration of certain diseases (hernia, mental problems) with the beginning or the end of any month. Time is also mentioned as important in gathering of medicinal herbs (Vysotskii 1903: 237, 239). In our collection too, a rare proverb alludes to a correlation between a season and certain health problems: Zimoi opasaisia kori, letom - ospy ('In winter be afraid of measles, while in summer - of the smallpox' - Turkmen) (Fialkov \& Fialkova 2009: 86), but this is by no means a general phenomenon. According to Elmquist, injuries are most often mentioned among the variety of health problems, while little information is given about psychic condition, sleep, doctors, hygiene, sex and social diseases. His finding is not confirmed by other collections, which emphasize the existence of numerous proverbs about doctors and sleep (Vysotskii 1903: 238-239; Fialkov \& Fialkova 2009: 96-109; Zakharov \& Zhungietu 1975: 208-212). Most authors agree on the importance of proverbs about diet, hygiene and alcohol. The names of products can vary. Thus Elmquist and Mieder indicate the large number of medical proverbs about fruit, meat, vegetables and drinks, while 
Vysotskii does not mention fruit or meat at all. Soup, salted cucumbers, bread, garlic, onion, point, butter, kasha and alcohol make up his menu based on proverbs (Elmquist 1934: 79; Mieder 1993: 153-154; Vysotskii 1903: 238-239). Vysotskii and Mieder, unlike Elmquist, highlight an abundance of proverbs on psychosomatic issues. F. H. Garrison perceives physiological and psychological observations, rather than notions of pathology which can be found in proverbs, to be of major importance for a physician (Garrison 1928: 984). For his part, Mieder notes the profusion of proverbs about sleep or the common cold, and the dearth of proverbs about Legionnaire's disease, organ transplants, AIDS, and so on (Mieder 1993: 153).

In Russian-language collections fruits are rarely mentioned in a strictly medical context. So the English proverb "An apple a day, keeps the doctor away" (Mieder 1993) is found only once (Sysoev 2007: 80). It appears also on the Internet in a couple of versions Kto iabloko $v$ den' siedaet, $u$ togo doktor ne byvaet ('Who eats an a apple a day, is not visited by the doctor'), Iabloko $v$ den', $i$ doktor ne nuzhen ('An apple a day and there is no need for a doctor') in sites on diet problems or regarding apples: http://www.passion.ru/s.php/6577.htm, http://www.yabloko.ru/Regions/Moscow/misc/lechenje.html.

On the other hand, Russian proverbs about onions and garlic are extremely popular: examples are Luk da bania vsie praviat ('The onion and the bathhouse cure everything'), Luk sem' nedugov lechit ('The onion cures seven diseases'), Chesnok sem' nedugov izvodit ('Garlic cures seven diseases'), Khren da red'ka, luk da kapusta khudogo ne pustiat ('Horseradish and radish, onion and cabbage will not lead to any harm'), Chesnok da red'ka - tak $i$ na zhivote krepko ('Garlic and radish make the stomach strong'), Esh' chesnok i luk - ne voz'miet nedug ('Eat garlic and onion and no disease will catch you') etc. (Fialkov \& Fialkova 2009: 69, 123; Sysoev 2007: 67; Vysotskii 1903: 238; Zakharov \& Zhungietu 1975: 141-142).

The list of diseases mentioned in the proverbs is indeed very limited. In addition to the common cold there are also other ailments, e.g., korosta ('scab'), mozol' ('callus'), chirei ('furuncle'), stomach problems, lameness, blindness and eye problems, toothache and illness resulting from distress. Occasional proverbs and proverbial sayings refer to hernia, Na molodu mesiatsu i gryzha besitsia ('When the moon is new, the hernia goes wild'), to diabetes, I sakharnaia bolezn' ne sladka ('Even a sugary disease is not sweet' - Russian), to measles, plague, typhus, cholera, smallpox, and elephantiasis: Vot tri kavalera - tif, chuma $i$ kholera ('Here are three cavaliers - typhus, plague and cholera' - Ukrainian), Kto ot chumy utselel, tot ot khmelia umer ('The one who survived the plague died of alcohol' - Adygea), Zimoi opasaisia kori, letom - ospy ('In winter be afraid of measles, in summer - of the smallpox' - Turkmen), Pleshivost', 
kharakter $i$ slonovuiu bolezn' odna smert' izlechit ('Baldness, character and elephantiasis can be cured only by death' - Bengali), Riaboi ospy ne boitsia ('A pockmarked person is not afraid of smallpox' - Russian)'1. Some extremely rare items about leprosy and consumption are also found: Prokazhiennomu $i$ bogatstvo ne v radost' ('A leprous person can't be happy even with wealth' African Malagasy); Prokazhennyi prokazhennogo i v temnote uznaet ('Lepers see each other even in the dark' - Uzbek), Ot fevralia do ianvaria kashlianul odnova, da i govorit: chakhotka ('From February till January he has coughed once, and says tuberculosis' - Russian), V griazi zhit', chakhotku nazhit' ('Living in the dirt means getting tuberculosis'-Russian), Piesh'vodku, nazhiviesh' - chakhotku ('He who drinks vodka will get tuberculosis' - Russian), (Fialkov \& Fialkova 2009: 85-86, 88; Sysoev 2007: 50, 58-59, 79; Zakharov \& Zhungietu 1975: 200).

Many proverbs involve alcohol. According to Vysotskii, moderate use of alcohol is perceived as healthful in folk wisdom: Posle supu vina vypit' - $u$ doktora chervonets ukrast' ('Drinking wine after soup means stealing ten roubles from the doctor') ${ }^{2}$, Khleb serdtse cheloveku ukrepliaet, a vino vozvesseliaet ('Bread makes the heart stronger while wine makes it cheerful'), but excessive use is censured (Vysotskii 1903: 238). Proverbs in favor of alcohol can be also found in contemporary Russian-language collections of medical proverbs if moderation is stressed (Fialkov \& Fialkova 2009: 152; Zakharov \& Zhungietu 1975: 167-168). They may be missed out when the collectors want to propagate sobriety and are not concerned with showing the diversity of the material (Sysoev 2007). Along with typical proverbs about the danger of alcohol, which are published in all collections, nowadays a number of proverbs are about drug addiction: $K$ narkotikam lipnut', ot nikh i gibnut' ('Sticking to drugs means dying from them' - Russian), Kto kurit travku i tabak, tot sam sebe zakliatyi vrag ('Whoever smokes grass and tobacco is his own worst enemy' - Russian), Narkomania v mogilu zamaniavet ('Drug addiction traps one in a tomb' - Russian), etc. (Sysoev 2007: 51-60). The absence of proverbs about drugs in earlier Russian-language collections may due to two processes: the limited number of drug addicts as against the high numbers of alcoholics and/or a censorship policy in Soviet publishing. Both circumstances changed drastically after the fall of the USSR.

I found no proverbs about AIDS in any printed collection, although they are easily traced on the Internet: Esli diadia s diadei spit, to u diadei budet spid ('If a man sleeps with another man, both will get AIDS'), http://mariinskoerejd.ru/modules/newbb/viewtopic.php?post_id=829, Esli diadia s tietei nezhen, spid u diadi neizbezhen ('If a man is tender to a woman, he will inevitably get AIDS') http://www.x-vim.info/s_28d6df8.html, Poka virus spit, $u$ tebia eshchie 
ne spid ('While the virus is still sleeping, you are not ill with AIDS yet') http://www.medbio-kgmu.ru/cgi-bin/go.pl?i=2311. ${ }^{3}$ It is difficult to assess whether these new proverbs are really popular. Still, I know for sure that the last quoted example was produced by the students in the medical genetics department at the University of Kazan as an assignment. The students were given guidance on how to create new proverbs: they could either take a well known proverb and change it according to a given biological phenomenon or first compose a brief description of the phenomenon and then through the key-words find a suitable proverb for subsequent modifications. The creation and dissemination of anti-drug and anti-alcohol proverbs may be a deliberate work of doctors and educators to influence the behaviour of the general public. The use of medical proverbs for indoctrination is not uncommon. For example, at a children's library a competition was held on knowledge of anti-alcohol proverbs: http:// nevinka.library.ru/program/struggle.php . This is one of the tools of Zhitnikova and Polivanova in their practical work (2001).

The Internet may be regarded as an appropriate place to search for new proverbs - serious and ironical including medical ones (Mieder 2008: 91-94, 101-102; Mieder 2008a: 133). Several variations of a well known proverb Luchshe sinitsa v rukakh, chem zhuravl'v nebe ('Better a titmouse in the hands than a crane in the sky') have an evident medical meaning: Luchshe sinitsa $v$ ruke, chem utka pod krovatiu ('Better a titmouse in the hands than a duck under the bed') http://www.bibo.kz/aforizmi/148728-luchshe-sinica-v-ruke-chemutka-pod-krovatju.html and Luchshe sinitsa $v$ rukakh, chem shvy na golove ('Better a titmouse in the hand than stitches on the head') http://www.bibo.kz/ aforizmi/148728-luchshe-sinica-v-ruke-chem-utka-pod-krovatju.html. It is important to note that "a duck under the bed" has nothing to do with ornithology: the duck here is a men's chamber pot which has a narrow duck-like neck. The same "duck" is used in the identical pattern "better $\mathrm{x}$ than $\mathrm{y}$ " with another medical meaning: Luchshe utka $i$ krovatka, chem kalitka $i$ ogradka ("Better a duck and a bed than a wicket and a fence [i.e. burial plot]') http:// 1504.livejournal.com/26983.html, where any illness is perceived as preferable to death. Sometimes the duck is lost although the meaning does not change: Luchshe gips $i$ krovatka, chem granit i ogradka ('Better gypsum and a bed than granite and a fence') http://504.livejournal.com/26983.html. These new humorous variations go hand in hand with older medical proverbs, e.g. "Better tooth out than always ache", "Better eye out than always ache", "Better cut the shoe than pinch the foot" (Elmquist 1934: 76). 


\section{CONCLUSION}

The perception of a proverb as a medical one is flexible and can vary from paper to paper and from collection to collection. In all thematic collections of proverbs the items are taken out of the context. Nevertheless, their very inclusion is a context-specifying factor. For example, the proverb Kakoi palets ne porezhesh' - bolit ('Any finger slashed - is in pain') (Fialkov \& Fialkova 2009: 76) may in another context refer not to fingers but to a child, whose suffering is painful for the mother regardless of the number of her children. The same is true of the proverb Skripuchee derevo ne legko lomaetsia ('A creaky tree is not easily cracked'). This German proverb and its Ukrainian counterparts in particular, when juxtaposed to the Polish proverb Boleznennyi dol'she zhiviet ('A sickly man lives longer') is obviously of medical character (Fialkov \& Fialkova 2009: 117-118). But this characteristic may be reduced if the same proverb is placed in a collection about plants prepared by a botanist. Conversely, it is quite easy to understand the Estonian proverb "An empty sack cannot stand upright", which has only a potential meaning (Krikmann 1974: 6), becoming medical in close proximity to such proverbs as $K$ oslabevshemu vse bolezni pristaiut ('All the diseases are glued to a weak one' - Bengali), Slabyi chelovek $i$ ot sorinki zaboleet ('A weak person will get ill even from a speck of dust' Tatar) (Fialkov \& Fialkova 2009: 112). Thematic collections of proverbs as a form of applied folklore tend to prescribe a meaning for the items included. Understandably, the authors of a paper, about the family expenditure on children as reflected in proverbs, indicated the inappropriateness of philological principles for their purpose. The reference here was to the Russian edition of Prof. Krikmann's paper on the indefiniteness of proverbs. For those authors' goal, the broadly understood semantic principle was found most suitable (Koroleva \& Sinitsa 2008). By taking this approach as against the proverbs test based on the different concrete-abstract grasp of proverbs by schizophrenics and healthy people, I must admit that I and other thematic compilers and researchers (e.g. Verkhovin 1998; Tsikhotskaia 1999, etc.) find ourselves amongst those producing so-called "false positive results" (Gorham 1956: 438). Nevertheless, thematic studies are as active as ever, and are conducted by folklorists and by members of other professions. This fact necessitates David J. Hufford's redefinition of applied folklore: it is "the application of concepts, methods and materials from academic folklore studies to the solution of practical problems" (Hufford 1994: 120). In my opinion, applied folklore is the application of materials and/or concepts from folklore and/or folklore studies to the solution of practical problems in various fields. It can be practiced by the repre- 
sentatives of academic and non-academic folklore studies and/or by specialists in fields where the application is needed. The wish to use proverbs for concrete purposes is a function of the material itself as much as of the quest for its universal formulas. All we should remember is that the validity of these results is no stricter than the definiteness of the genre.

\section{NOTES}

${ }^{1}$ Vysotskii states that this specific proverb can be medically explained as the fact that certain diseases usually attack people only once in their lifetime (Vysotskii 1903: 237).

2 This proverb can be seen as yet another Russian variation on "An apple a day...".

${ }^{3}$ All the sites quoted were last accessed on 20 Nov 2010.

\section{REFERENCES}

Al-Krenawi, Alean 2000. Bedouin-Arab Clients' Use of Proverbs in the Therapeutic Settings. International Journal for the Advancement of Counselling, Vol. 22, No. 2, pp. 91-102.

Anonymous 1914. Proverbial Medicine: The Weather and Medical Proverbs about Yule and May. The British Medical Journal, Vol. 1, No. 2781 (18 of April), pp. 873875.

Dal', Vladimir 1957. Poslovitsy ruskogo naroda. [Proverbs of the Russian People]. Moscow: Gosudarstvennoe izdatel'stvo khudozhestvennoi literatury, pp. 278-290, 397-404.

Dudnikov, P. F. 1969. Mudroe slovo o zdorov'e. [A Wise Word about Health]. Moscow: Znanie.

Dunaevskii, S. G. 1965. Mudrost' narodnuiu - na sluzhbu zdorov'iu. [Folk Wisdom in the Service of Health]. Moskva: Institut sanitarnogo prosveshchenia Minzdrava SSSR.

Dundes Alan 1994. On the Structure of Proverb. In: W. Mieder \& A. Dundes (eds.) The Wisdom of Many: Essays on the Proverb. Madison, Wisconsin: University of Wisconsin Press, pp. 43-64.

Dundes, Alan \& Dundes, Lauren \& Streiff, Michael 2008. "When You Hear Hooofbeats, Think Horses, Not Zebras": A Folk Medical Diagnostic Proverb. In: A. Dundes "The Kushmaker" and Other Essays on Folk Speech and Folk Humor. Edited by Wolfgang Mieder. Supplement Series of Proverbium 26, pp. 21-29.

Elmquist, Russell A. 1934. English Medical Proverbs. Modern Philology, Vol. 32, No. 1, pp. 75-84. http://www.jstor.org/pss/434185, last accessed 10 Dec 2010.

Fialkov Lev \& Fialkova Larisa (eds.) 2009. Narody mira o zhizni i smerti, Zdorovie $i$ bolezni, bol'nykh i vrachakh: Poslovitsy i pogovorki. [The Peoples of the World on 
Life and Death, Health and Sickness, Sick People and Doctors: Proverbs and Sayings]. Haifa: JKDesign.

Garrison, Fielding H. 1928. Editorial: Medical Proverbs, Aphorisms and Epigrams. Bulletin of the New York Academy of Medicine, Vol. 4, No. 10, pp. 979-1005. http://www.pubmedcentral.nih.gov/picrender.fcgi?artid=2393983\&blobtype=pdf, last accessed on 20 Nov 2010.

Gorham, Donald R. 1956. Use of the Proverbs Test for differentiating schizophrenics from normals. Journal of Consulting Psychology, Vol. 20, No. 6, pp. 435-440.

Hufford, David J. 1994. Folklore and Medicine. In: M. O. Jones (ed.) Putting Folklore to Use. Lexington: University Press of Kentucky.

Jackson, Vera 1995. Proverbs: A Tool for Work with Older Persons. In: V. Jackson (ed.) Aging Families and Use of Proverbs for Values Enrichment. Binghamton, NY: The Haworth Press, pp. 5-14.

Kadymov, Shaik 1971. Bolen - lechis', a zdorov - beregis'. [If you are ill - doctor yourself, if you are healthy - take care of yourself]. Baku: Azerbaidzhanskoe gosudarstvennoe izdatel'stvo.

Koroleva, Maria V. \& Sinitsa Aresnii L. 2008. Poslovitsy o raskhodakh na detei kak predmet sotsial'no-demograficheskogo issledovaniia. [Proverbs about expenditure on children as a subject of social and demographic research]. Demoskop Weekly, No. 353-354. http://www.demoscope.ru/weekly/2008/0353/analit09.php, last accessed on 20 Nov 2010.

Krikmann, Arvo 1974. On Denotative Indefiniteness of Proverbs: remarks on proverb semantics 1. Tallinn: Academy of Sciences of the Estonian SSR. http:// www.folklore.ee/ kriku/PROVERBS/ProvSemIndef1.pdf, last accessed on 20 Nov 2010 .

Krikmann, Arvo 2001. Proverbs on Animal Identity: Typological Memoirs. Folklore: Electronic Journal of Folklore, Vol. 17, pp. 7-84.

Mieder, Wolfgang 1993. An Apple a Day Keeps a Doctor Away: Traditional and Modern Aspects of Medical Proverbs. In: W. Mieder (ed.) Proverbs Are Never Out of Season. Popular Wisdom in the Modern Age. New York: Oxford University Press, pp. $152-172$.

Mieder, Wolfgang 2004. Sociology, Psychology and Psychiatry. In: W. Mieder Proverbs: A Handbook. Westport, CT \& Oxford: Greenwood Press, pp 139-142.

Mieder, Wolfgang 2008. "Anti-Proverbs and Mass Communication”: Interplay of Traditional and Innovative Folklore. In: W. Mieder "Proverbs Speak Louder Than Words": Folk Wisdom in Art, Culture, Folklore, History, Literature and Mass Media. New York: Peter Lang, pp. 87-119.

Mieder, Wolfgang 2008a. "It Pays To Proverbialize": Folk Wisdom in the Modern Mass Media. In: W. Mieder "Proverbs Speak Louder Than Words": Folk Wisdom in Art, Culture, Folklore, History, Literature and Mass Media. New York: Peter Lang, pp. 121-141.

Sponheim, Scott R. \& Surerus-Johnson, Christa \& Leskela, Jennie \& Dieperink, Michael E. 2003. Proverb Interpretation in Schizophrenia: The Significance of Symptomatology and Cognitive Processes. Schizophrenia Research, Vol. 65, No. 2-3, pp. 117-123. 
Stoianova, Inga. 2007. Informal medical discourse: notes on specialized slang, jargon and proverbs. Intertext, Vols. 1-2, pp. 136-143.

Sysoev, Viacheslav 2007. Zdorov'e vsego dorozhe. [The Health is the Most Valuable Wealth]. Moskva: AST.

Tsikhotskaia A. I. 1999. Iuridicheskie poslovitsy kak iavlenie natsional'noi pravovoi kul'tury. [Legal Proverbs as a Phenomenon of a National Legal Culture]. In: A. V. Tsikhotskii \& G. L. Osokina \& M. I. Kleandrov (eds.) Sovremennye problemy iurisprudentsii. [Contemporary Problems of Jurisprudence]. Novosibirsk: Sibirskii universitet potrebitel'skoi kooperatsii, pp. 40-49.

Ulatowska, Hanna K. \& Chapman, Sandra Bond \& Johnson, Julene K. 1995. Processing of Proverbs in Aphasics and Old-Elderly. Clinical Aphasiology, Vol. 23, pp. 179-193. http://aphasiology.pitt.edu/archive/00000199/01/23-15.pdf, last accessed on 20 Nov 2010.

Verkhovin, Vladimir I.1998. Ekonomicheskie stereotipy v russkom fol'klore. [Economic Stereotypes in Russian Folklore]. Sotsis, Vol. 6, pp. 82-88.

Vysotskii, Nikolai Fedorovich 1903. Meditsinskie vozzreniia nashego naroda v poslovitsakh i pogovorkakh. [Medical Views of Our People in Proverbs and Sayings, in Russian]. Istoricheskii Vestnik: Istoriko-Literaturnyi Zhurnal [Historical Herald: Historical and Literary Journal], No. 7 (July), pp. 235-2 41.

Zakharov, Vladimir \& Zhungietu, Efim 1975. Zdorov'e v rukakh cheloveka: Poslovitsy, pogovorki i aforizmy raznykh narodov. [Health is in the Hands of a Man: Proverbs and Sayings of Various Peoples]. Kishinev: Shtiintsa.

Zhitnikova, T. L. \& Polivanova, E. A. 2001. Anekdoty, poslovitsy i pogovorki v pomoshch' psikhologu v narkologii. [Jokes, Proverbs and Sayings as a Help to an Expert in Narcology]. Moscow: NAN. http://lepila.tyurem.net/topic110.html, no longer available. 